\title{
Review
}

\section{An Updated Systematic Review of the Diagnostic Utility of Selective Nerve Root Blocks}

Sukdeb Datta, MD', Clifford R. Everett, MD², Andrea M. Trescot, MD³, David M. Schultz, MD4, Rajiv Adlaka, MD, Salahadin Abdi, MD, PhD', Sairam L. Atluri, MD7,

Howard S. Smith, MD, $\mathrm{PhD}^{8}$, and Rinoo V. Shah, $\mathrm{MD}^{9}$

From: ${ }^{1}$ Vanderbilt University School of Medicine, Nashville, TN; ${ }^{2}$ University of Rochester Medical Center, Rochester, NY; ${ }^{3}$ University of Florida, Gainesville,

FL; 4 University of Minnesota Medical School, Minneapolis, MN; ${ }^{5}$ Pain Control Associates, Munster, IN; ${ }^{6}$ University of Miami Pain Center, Miami, FL; ${ }^{7}$ Tristate Pain Management, Loveland, $\mathrm{OH}$;

${ }^{8}$ Albany Medical College, Albany, NY; ${ }^{9}$ Guthrie Clinic, Horsehead, NY

Dr. Datta ${ }^{1}$ is Assistant Professor, Department of Anesthesiology, Vanderbilt University School of Medicine, and Director Pain Management Services VA Tennessee Valley Healthcare System, Nashville, TN; Dr. Everett ${ }^{2}$ is Associate Professor, University of Rochester Medical Center, Rochester, NY. Dr. Trescot ${ }^{3}$ is Director, Pain Fellowship Program, University of Florida, and The Pain Center, Orange Park, FL.

Dr. Schultz ${ }^{4}$, is Assistant Professor, Department of Anesthesiology, University of Minnesota Medical School and Medical Director, MAPS Medical Pain Clinics, Minneapolis, MN. Dr. Adlaka5 is Medical Director, Pain Control Associates, Munster, IN. Dr. Abdi ${ }^{6}$ Professor and Chief, University of Miami Pain Center, Department of Anesthesiology, Perioperative Medicine and Pain Management, Miami, FL. Dr. Atluri ${ }^{7}$, Tristate Pain Management,

Loveland, OH. Dr. Smith ${ }^{8}$ is Academic Director of Pain Management,

Professor of Anesthesiology, Albany Medical College, Albany, NY. Dr. Shah', Interventional Pain Management Department of Anesthesiology, Guthrie Clinic, Big Flats, Horsehead, NY Address Correspondence:

Sukdeb Datta, MD, VA Tennessee Valley Healthcare System, 1310 24th Avenue South, Nashville, TN 37212

E-mail sukdeb@hotmail.com Funding: None. Conflict of Interest: None.

Free Full manuscript: www.painphysicianjournal.com
Background: Selective nerve root blocks or transforaminal epidural injections are used for diagnosis and treatment of different spinal disorders. A clear consensus on the use of selective nerve root injections as a diagnostic tool does not currently exist. Additionally, the effectiveness of this procedure as a diagnostic tool is not clear. A systematic review of diagnostic utility of selective nerve root blocks was performed and published in January 2005, which concluded that selective nerve root injections may be helpful as a diagnostic tool in evaluating spinal pain with radicular features, but its role needs to be further clarified.

Objective: To evaluate and update the accuracy of selective nerve root injections in diagnosing spinal disorders.

Study Design: A systematic review of selective nerve root blocks for the diagnosis of spinal pain.

Methods: A systematic review of the literature for clinical studies was performed to assess the accuracy of selective nerve root injections in diagnosing spinal pain. Methodologic quality evaluation was performed utilizing Agency for Healthcare Research and Quality (AHRQ) and Quality Assessment Studies of Diagnostic Accuracy (QUADAS) criteria. Studies were graded and evidence classified into 5 levels: conclusive, strong, moderate, limited, or indeterminate. An extensive literature search was performed utilizing resources from the library at Vanderbilt University Medical Center, PubMed, EMBASE, BioMed, and Cochrane Reviews. Manual searches of bibliographies of known primary and review articles, and abstracts from scientific meetings within the last 2 years were also reviewed.

Results: There is limited evidence on the effectiveness of selective nerve root injections as a diagnostic tool for spinal pain. There is insufficient research for stronger support, but the available literature is supportive of selective nerve root injections as a diagnostic test for equivocal radicular pain. There is moderate evidence for use in the preoperative evaluation of patients with negative or inconclusive imaging studies. The positive predictive value of diagnostic selective nerve root blocks is low, but they have a useful negative predictive value.

Conclusion: Selective nerve root injections may be helpful as a diagnostic tool in evaluating spinal pain with radicular features. However, their role needs to be further clarified by additional research and consensus.

Keywords: Selective nerve root block, transforaminal epidural injection, spinal pain, discogenic pain, radiculopathy, nerve root pain

Pain Physician 2007; 10:113-128 
P ain originating from the spine is frequently difficult to diagnose with specificity as imaging abnormalities found on imaging studies are frequently painless (1-13). Excluding fractures, disorders of the spine that produce pain can be categorized as compressive, inflammatory, degenerative, or multifactorial.

For a structure to be painful it must have a nerve supply (10), capable of producing pain described clinically, and be susceptible to disease or injury. Methods have been developed to test painful structures using fluoroscopically- (x-ray) guided injections of local anesthetics. If a structure is selectively anesthetized and the individual describes pain relief for the duration of action of the anesthetic, that structure is determined to be the source of pain (10). For compressive and inflammatory disorders of spinal nerve roots, the likely area for this to occur is within the bony channel created between adjacent vertebrae at the neural foramen (11).

Spinal injections have received considerable interest regarding therapeutic effect. Specifically, the use of epidural steroid injections in the treatment of spinal disorders has progressed as the procedures have become more exact with the aid of fluoroscopic or CT guidance (2-9). The indications include radicular pain, spinal stenosis, and lower back pain related to a discogenic cause (2-9,13-26). However, the foraminal and nerve root injections as diagnostic tools do not have a consistent method of application. In fact, controversy exists in the nomenclature $(1,2-5,16-21,25-29)$. Manchikanti and Singh $(26,30)$ noted that the terminology describing transforaminal injections has varied from nerve root injections to selective nerve root blocks, selective nerve root sleeve injections, selective epidurals, selective spinal nerve blocks, selective ventral ramus blocks and periradicular injections. Bogduk (31) described it (i.e. technique) as a lumbar nerve block, a procedure in which an aliquot of local anesthetic is delivered onto lumbar spinal nerve (or the $\mathrm{SI}$ spinal nerve) in order to anesthetize the nerve and its roots selectively.

Gajraj (32) noted that "...to be selective, a nerve root block should be performed extraforaminally, distal to the division of the ventral and dorsal rami; otherwise the dorsal rami and all its innervated structures will also be anesthetized...it has therefore been suggested that the therapeutic procedure be referred as a 'transforaminal epidural steroid injection' and that the diagnostic procedure be referred to as a 'selective spinal block' or 'selective ventral ramus block.'"
In an attempt to clarify the issue, Datta and Pai (34) noted that the term "transforaminal" is a misnomer and gives a false sense of the needle traversing the foramen, when essentially the needle position is paraforaminal. They also noted that the term "selective nerve root block" should be rephrased as a "paraforaminal injection" because no preferential distribution of the intended medication occurs to the ventral ramus. Other suggested nomenclature include the terms "periradicular," "nerve root infiltration (NRI)," "transforaminal selective nerve root block," "segmental nerve root block," and "lumbar nerve block" (1$4,25,26,29,31,34-36)$.

In the United States, the official language for this procedure is transforaminal epidural injection. There is no other code to communicate with insurers and the government. A few use anesthetic alone; others use a smaller steroid dose, arguing that the steroid should not have an immediate response. The volumes used in the injection also vary by physician with some using a larger volume and others using a volume consistent with the amount necessary to reach the lateral recess. Manchikanti and Singh $(26,30)$ noted that Karppinen et al $(17,25,29)$ injected contrast of $0.5-1.0 \mathrm{~mL}$ for diagnostic purposes followed by a therapeutic injection of methylprednisone $40 \mathrm{mg}$, bupivacaine, or isotonic sodium chloride solution in a volume of $2 \mathrm{~mL}$ for $\mathrm{L} 4$ or $\mathrm{L} 5$ blocks and $3 \mathrm{~mL}$ for $\mathrm{S1}$, presumably based on anatomical differences. Higher volumes of injectate may result in extensive blockade similar to an interlaminar injection, even though ventral placement may still be an advantage. Purists insist on describing selective nerve root block and transforaminal injections as two separate and distinct techniques. Over the years, many have used them interchangeably. Despite the variance in practice, the technique holds promise as a diagnostic tool, but the reliability is unclear (26,37-39).

The value of provocative and analgesic spinal injections was recognized in 1938 by Steindler and Luck (37). MacNab (38) in 1971 demonstrated the value of diagnostic selective nerve root blocks in the preoperative evaluation of patients with negative or inconclusive imaging studies and clinical findings of nerve root irritation. Since then, nerve blocks have been used to diagnose the source of radicular pain when imaging studies suggested possible compression of several nerve roots (38-48).

The rationale for a diagnostic spinal nerve block is that if a particular spinal nerve is responsible for 
causing or mediating a patient's symptoms, then anesthetizing that nerve should temporarily relieve symptoms (31). Bogduk (31) further suggested that if the symptom is pain, anesthetization of the responsible nerve should relieve that pain. If the symptom is paraesthesia, anesthetizing the responsible nerve should produce numbness in the territory in which the paresthesia was previously felt. If the symptom is numbness, anesthetizing the responsible nerve should produce no change in the numbness, or perhaps accentuate it. Further, Bogduk (31) postulated that if a nerve is anesthetized that is not responsible for the patient's symptoms, pain will not be relieved and numbness will occur in a distribution that does not correspond to the distribution in which the patient ordinarily experiences paresthesia or numbness.

Lumbar spinal nerve blocks have been considered to have concept validity because anesthetizing a nerve should relieve symptoms mediated by that nerve. Face validity is established by administering the injection under fluoroscopy with the injection of a contrast medium outlining the target nerve root and contrast not spreading to other structures. To establish construct validity of the test, selective nerve root blocks must be performed under controlled conditions to avoid falsepositive results. Thus far, there are no descriptions of the procedure for this purpose. Thus, when selective nerve root blocks are indicated, they have been assumed to have no false-positive effects (31).

In 1992, Nachemson (49) analyzed the literature on low back pain and concluded that diagnostic, selective nerve root blocks provided important prognostic information about surgical outcomes. Van Akkerveeken (46) described the sensitivity, specificity, and predictive value for diagnostic, selective nerve root blocks. He also showed that for a block to be determined positive, it required concurrent symptom reproduction during root stimulation and full relief of pain following anesthetic infusion.

This systematic review was performed to determine if selective nerve root injections are an effective method for diagnosing spinal disorders. The present review is an update of a previous systematic review in 2005 (1)

\section{Methods}

\section{Inclusion Criteria}

Types of Studies

Included in the analysis were controlled and un- controlled clinical studies with diagnostic selective nerve root injections as a part of the study design.

Types of Participants

Subjects with pain of spinal origin

Types of Interventions

Selective nerve root injections performed under fluoroscopic guidance

Types of Outcome Measures

Pain relief, correlation with other diagnostic tests or therapeutic outcomes

\section{Exclusion Criteria}

Types of Studies

Non-clinical studies, expert opinion, or clearly therapeutic studies

Types of Interventions

Non-selective nerve injections, with the route of administration not specifically described were assumed to be interlaminar and for the purposes of this review and rejected.

Search Strategy

Relevant clinical trials meeting the inclusion criteria for this review were identified in the following manner:

1. A professional librarian familiar with EBL searches from Vanderbilt performed the search on July 14,2006 . The search strategy is documented in a tabular form (Table 1). PubMed strategies included a keyword search of non-Medline citations to retrieve in-process and supplied by publisher citations. Further searches were performed using EMBASE and ISI Web of Science databases. Results from the three databases were combined and duplicates removed.

2. A review of the reference sections of the articles selected was also performed to identify additional studies for potential inclusion.

3. Abstracts were then incorporated for review as a Reference Manager file "Epidural Steroids." All members of the group then received hard copies of the abstracts. Abstracts then were selected for review and full articles were then reviewed by at least three authors.

4. Ongoing review and search of newer articles was done by the study authors, concluding in December 2006. This included manual searches of common databases by the authors for newer articles not identified by the librarian search.

\section{Method of Review}


Table 1. Search strategy employed using a professional librarian experienced in search strategies utilizing Evidence Based Medicine

\begin{tabular}{|c|c|c|}
\hline \multicolumn{3}{|c|}{ EMBASE } \\
\hline \#25 & $\begin{array}{l}\text { THORACIC SPINE/ or CERVICAL SPINE FRACTURE/ or LUMBAR SPINE/ or THORACOLUMBAR } \\
\text { SPINE/ or SPINE DISEASE/ or CERVICAL SPINE DISLOCATION/ or SPINE INJURY/ or SPINE FUSION/ or } \\
\text { LUMBOSACRAL SPINE/ or CERVICAL SPINE/ or CERVICAL SPINE INJURY/ or ANTERIOR SPINE FUSION/ } \\
\text { or SPINE SURGERY/ or SPINE FRACTURE/ or SPINE/ or RADICULOPATHY/ or LUMBAR DISK HERNIA/ or } \\
\text { RADICULAR PAIN/ or "Nerve Root Compression"/ or exp BACKACHE/ }\end{array}$ & 18916 \\
\hline \#26 & $\begin{array}{l}\text { intraspinal drug administration/ or epidural drug administration/ or intrathecal drug administration/ or epidural } \\
\text { steroid.sh. or ei.fs. or Epidural Space/ or transforaminal.mp. or ("epidural steroid" or "epidural corticosteroid").ti,ab. }\end{array}$ & 18036 \\
\hline$\# 29$ & $\begin{array}{l}{ }^{*} \text { STEROID THERAPY/ or exp }{ }^{*} \text { CORTICOSTEROID THERAPY/ or }{ }^{\star} \text { STEROID/ or exp }{ }^{*} \text { CORTICOSTEROID/ or } \\
\text { methylprednisolone acetate/ or triamcinolone diacetate/ }\end{array}$ & 160016 \\
\hline$\# 30$ & 25 and 26 and 29 & 432 \\
\hline $3 \# 1$ & limit 30 to (English language and yr=“2001 - 2006”) & 146 \\
\hline \multicolumn{3}{|c|}{ PubMed } \\
\hline$\# 21$ & 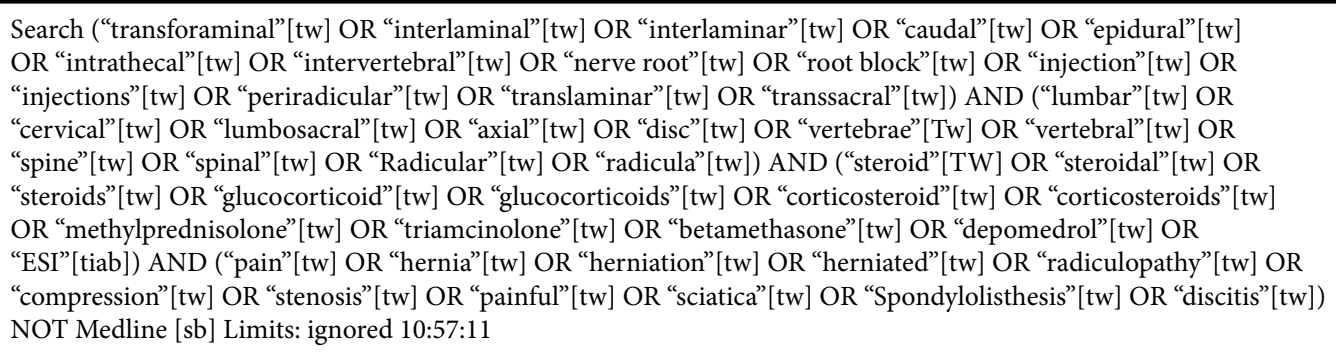 & 52 \\
\hline$\# 23$ & 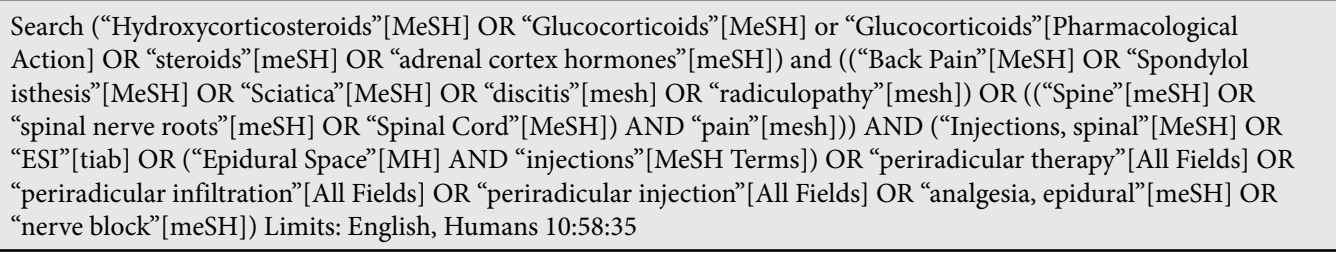 & 300 \\
\hline$\# 25$ & Search $((\# 23))$ OR $(\# 21)$ 10:59:00 & 352 \\
\hline & Search $((\# 23))$ OR (\#21) Limits: published in the last 5 years 11:51:21 & 157 \\
\hline \multicolumn{3}{|c|}{ ISI Web of Science } \\
\hline$\# 1$ & 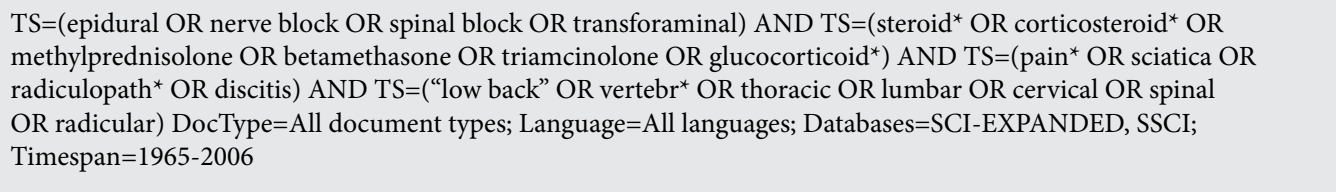 & 410 \\
\hline$\# 2$ & $\begin{array}{l}\# 1 \\
\text { DocType=All document types; Language=English; Databases=SCI-EXPANDED, SSCI; Timespan=2001-2006 }\end{array}$ & 196 \\
\hline
\end{tabular}

ISI- Institute of Scientific Information

The computerized database search, including the author, title, keywords, and abstract was printed and reviewed for exclusion criteria. If no clear exclusion criteria were identified within the abstract, the full journal article was obtained for review. The articles were reviewed by 3 physician reviewers, followed by further discussion by all others in the group. Articles were then abstracted for specific information on study design, number of patients, outcome studied, duration of study, and quality of study.

\section{Methodological Quality}

Quality of each individual article was evaluated by AHRQ (50) and QUADAS (51) criteria as shown in Tables 2 and 3. 


\section{Strength of Evidence}

The level of evidence was evaluated as shown in Table 4.

\section{Results}

\section{Literature Search}

The database search yielded 336 articles which were reviewed for inclusion or exclusion. For excluded articles, specific reasons were documented in the database article log. Of the 336 articles, 13 were selected for review and abstracting. A further review of the 13 articles led to the exclusion of 7 articles as being primarily therapeutic (52-58). The ongoing manual search by the authors led to 2 more articles being included in the review $(35,36)$. Eight articles were identified from the previous systematic review (1).

\section{Methodological Quality}

Multiple articles were excluded as they were clinical outcome studies and not diagnostic studies (14-23,59-63). Reference lists for the selected articles were reviewed and yielded an additional 8 articles. A total of 16 articles were selected for study (Fig. 1). The 16 studies are summarized in Table 5 (34-36,39$43,46,47,63-68)$.

\section{Rationale}

In general, imaging studies can accurately demonstrate disc herniation or nerve root compression. However, it is necessary to differentiate symptomatic from asymptomatic nerve compression in cases of multiple sites or levels of involvement, or in situations with confounding clinical features. The underlying principle of selective nerve root local anesthetic injection is the premise that a local anesthetic will act only locally at the site of nerve root pain generation. Consequently, it is presumed that any system effect of a local anesthetic is minimal.

\section{Study Characteristics}

Salient features of included studies are shown in Table 5.

Slipman et al (64) examined the effects of mechanical stimulation on 87 patients and examined 134 cervical nerve roots. The patients then described to an independent observer the referred symptoms, (dynatome) on a pain diagram. This dynatomal map was compared to classic dermatomal maps. The dynatomal map distribution was similar to classic dermatomal maps, but frequently overlapped other dermatomes and had a larger distribution. This study emphasized the potential importance and advantage of a selective

Table 2. Domains and elements for diagnostic studies developed by the Agency for Healthcare Research and Quality (AHQR)

\begin{tabular}{|c|c|}
\hline Domain $^{\#}$ & Elements* \\
\hline Study Population & $\begin{array}{l}\text { - Subjects similar to populations in which the test would be used and with a } \\
\text { similar spectrum of disease }\end{array}$ \\
\hline Adequate Description of Test & - Details of test and its administration sufficient to allow for replication of study \\
\hline Appropriate Reference Standard & $\begin{array}{l}\text { - Appropriate reference standard (gold standard) used for comparison } \\
\text { - Reference standard reproducible }\end{array}$ \\
\hline Blinded Comparison of Test and Reference & $\begin{array}{l}\text { - Evaluation of test without knowledge of disease status, if possible } \\
\text { - Independent, blind interpretation of test and reference }\end{array}$ \\
\hline Avoidance of Verification Bias & $\begin{array}{l}\text { - Decision to perform reference standard not dependent on results of test under } \\
\text { study }\end{array}$ \\
\hline \multicolumn{2}{|c|}{$\begin{array}{l}\text { \# Key domains are in italics } \\
\text { *Elements appearing in italics are those with an empirical basis. Elements appearing in bold are those considered essential to give a system a Yes } \\
\text { rating for the domain. }\end{array}$} \\
\hline
\end{tabular}


Table 3 Items utilized for assessment of quality of individual articles of diagnosti c studies by QUADAS tool

\begin{tabular}{|c|c|c|c|c|}
\hline Item & & Yes & No & Unclear \\
\hline 1. & $\begin{array}{l}\text { Was the spectrum of patients representative of the patients who will receive the test in } \\
\text { practice? }\end{array}$ & ( ) & () & ( ) \\
\hline 2. & Were selection criteria clearly described? & () & () & () \\
\hline 3. & Is the reference standard likely to correctly classify the target condition? & ( ) & ( ) & ( ) \\
\hline 4. & $\begin{array}{l}\text { Is the time period between reference standard and index test short enough to be } \\
\text { reasonably sure that the target condition did not change between the two tests? }\end{array}$ & ( ) & ( ) & () \\
\hline 5. & $\begin{array}{l}\text { Did the whole sample, or a random selection of the sample, receive verification using a } \\
\text { reference standard of diagnosis? }\end{array}$ & $($ ) & ( ) & ( ) \\
\hline 6. & Did patients receive the same reference standard regardless of the index test result? & ( ) & ( ) & () \\
\hline 7. & $\begin{array}{l}\text { Was the reference standard independent of the index test (i.e., the index test did not } \\
\text { form part of the reference standard)? }\end{array}$ & $($ ) & ( ) & () \\
\hline 8. & $\begin{array}{l}\text { Was the execution of the index test described in sufficient detail to permit replication } \\
\text { of the test? }\end{array}$ & ( ) & ( ) & () \\
\hline 9. & $\begin{array}{l}\text { Was the execution of the reference standard described in sufficient detail to permit its } \\
\text { replication? }\end{array}$ & ( ) & () & () \\
\hline 10. & $\begin{array}{l}\text { Were the index test results interpreted without knowledge of the results of the } \\
\text { reference standard? }\end{array}$ & $($ ) & () & () \\
\hline 11. & $\begin{array}{l}\text { Were the reference standard results interpreted without knowledge of the results of the } \\
\text { index test? }\end{array}$ & ( ) & ( ) & $($ ) \\
\hline 12. & $\begin{array}{l}\text { Were the same clinical data available when test results were interpreted as would be } \\
\text { available when the test is used in practice? }\end{array}$ & $($ ) & ( ) & () \\
\hline 13. & Were uninterpretable/intermediate test results reported? & () & () & ( ) \\
\hline 14. & Were withdrawals from the study explained? & $($ ) & ( ) & ( ) \\
\hline
\end{tabular}

Adapted from ref. 51

Table 4. Designation of levels of evidence

\begin{tabular}{|l|l|}
\hline Level I & $\begin{array}{l}\text { Conclusive: Research-based evidence with multiple relevant and high-quality scientific studies or consistent reviews of meta- } \\
\text { analyses . }\end{array}$ \\
\hline Level II & $\begin{array}{l}\text { Strong: Research-based evidence from at least one properly designed, randomized, controlled trial; or research-based evidence } \\
\text { from multiple properly designed studies of smaller size; or multiple low quality trials. }\end{array}$ \\
\hline Level III & $\begin{array}{l}\text { Moderate: a) Evidence obtained from well-designed pseudorandomized controlled trials (alternate allocation or some other } \\
\text { method); b) evidence obtained from comparative studies with concurrent controls and allocation not randomized (cohort studies, } \\
\text { case-controlled studies, or interrupted time series with a control group); c) evidence obtained from comparative studies with } \\
\text { historical control, two or more single-arm studies, or interrupted time series without a parallel control group. }\end{array}$ \\
\hline Level IV & $\begin{array}{l}\text { Limited: Evidence from well-designed nonexperimental studies from more than one center or research group; or conflicting } \\
\text { evidence with inconsistent findings in multiple trials. }\end{array}$ \\
\hline Level V & Indeterminate: Opinions of respected authorities, based on clinical evidence, descriptive studies, or reports of expert committees. \\
\hline
\end{tabular}




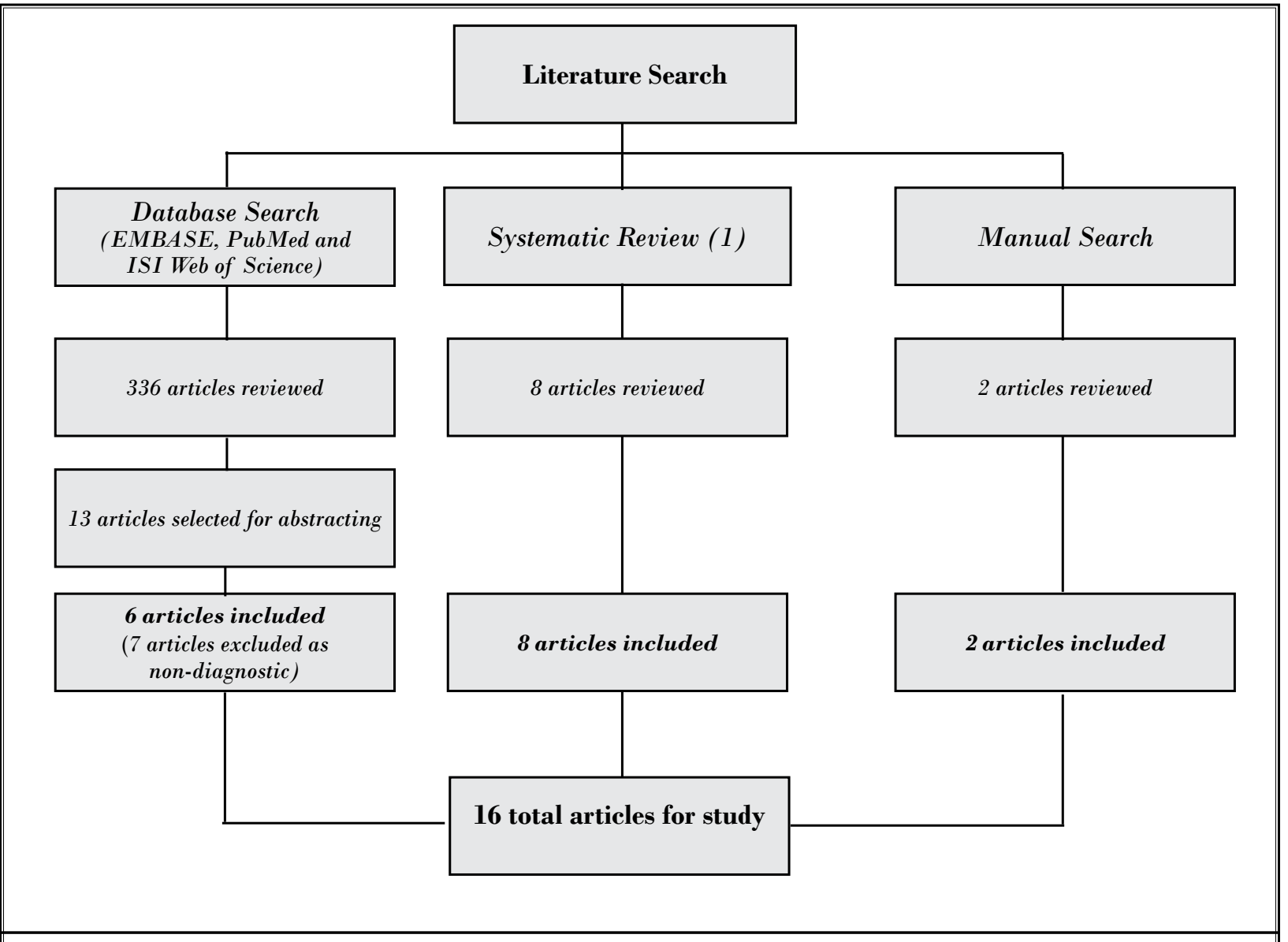

Fig. 1. Systematic review flow sheet

nerve root block in evaluating patients with equivocal imaging and radicular pain.

Wolff et al (65) examined the hypesthetic area following a lumbar selective nerve root block and compared this to classic dermatomal maps. They found that the hypesthetic area overlapped more than one classic dermatome. The addition of hypesthetic response to paresthesias and blockade of pain provided a method of diagnosing clinically relevant spinal levels. In a followup study by the same group (35), 10 consecutive patients underwent 20 controlled diagnostic selective nerve root block at $\mathrm{L} 4$ with ropivacaine $0.25 \%$ or lidocaine $1 \%$ in a prospective double blind, crossover fashion. Each patient underwent on separate occasions 2 test blocks with the 2 local anesthetic agents in a random order. The selective nerve blocks were performed under fluoroscopic guidance using sensory and motor electrostimulation. They found that asymptomatic hypesthesia, variable in ex- tent and non-dermatomal in distribution, was present in 7 of 10 patients at baseline. It appeared to be more extensive and distal with a longer duration of pre-existing pain. The selective nerve root block produced no consistent changes in extent and distribution of hypoesthetic areas. Changes in pain did not correlate with the extent of pre-block or post-block hypesthesia. The study could be criticized for its small sample size, and one patient had a herniated L5-S1 but had a L4 selective nerve root injection performed.

Wolff et al (36) have also studied the influence of needle position on lumbar segmental nerve root block selectivity. Patients scheduled for L4, L5, and S1 blocks were included in a prospective observational study. Under fluoroscopy and electrostimulation, patients received $0.5 \mathrm{~mL}$ of a mixture of lidocaine $5 \mathrm{mg}$ and iohexol $75 \mathrm{mg}$. They found that lumbar epidural spread to adjacent nerve roots, which resulted in decreased selective nerve root block selectivity being 
Pain Physician: January 2007:10:113-128

Table 5. Characteristics of articles included in systematic review of selective nerve root blocks.

\begin{tabular}{|c|c|c|c|c|c|}
\hline $\begin{array}{l}\text { Study/ } \\
\text { Methods }\end{array}$ & Participants & Interventions & Outcomes & Results & Outcomes/Conclusion \\
\hline $\begin{array}{l}\text { Anderberg et al (68) } \\
\text { Prospective cohort } \\
\text { AHRQ score } 4 / 5 \\
\text { QUADAS score } \\
11 / 14\end{array}$ & 20 patients & \begin{tabular}{|l|} 
Nerve block with \\
MRI and surgical \\
correlation in \\
cervical radicular \\
pain
\end{tabular} & $\begin{array}{l}\text { VAS and surgical } \\
\text { outcome }\end{array}$ & $\begin{array}{l}18 / 20 \text { with good relief post } \\
\text { block had surgery with none } \\
\text { having radicular pain after } \\
\text { surgery }\end{array}$ & $\begin{array}{l}\text { Positive surgical response } \\
\text { with positive SNRB }\end{array}$ \\
\hline $\begin{array}{l}\text { Slipman et al (64) } \\
\text { Prospective study } \\
\text { AHRQ score } 4 / 5 \\
\text { QUADAS score } 11 / 14\end{array}$ & 87 patients & $\begin{array}{l}\text { Cervical nerve } \\
\text { root mechanical } \\
\text { stimulation }\end{array}$ & $\begin{array}{l}\text { Pain mapping } \\
\text { diagram }\end{array}$ & $\begin{array}{l}\text { Dermatomal maps differ from } \\
\text { dynatomal maps }\end{array}$ & $\begin{array}{l}\text { Referral patterns may differ } \\
\text { from classic dermatomal } \\
\text { maps }\end{array}$ \\
\hline $\begin{array}{l}\text { Wolff et al (65) } \\
\text { Prospective study } \\
\text { AHRQ score } 4 / 5 \\
\text { QUADAS score } 10 / 14\end{array}$ & 29 patients & $\begin{array}{l}\text { Selective nerve } \\
\text { root injections }\end{array}$ & $\begin{array}{l}\text { Sensory testing } \\
\text { after SNRB }\end{array}$ & $\begin{array}{l}\text { Hypesthetic areas post block } \\
\text { were variable and larger than } \\
\text { paresthetic areas preblock. }\end{array}$ & $\begin{array}{l}\text { Nerve root block patterns } \\
\text { may differ from classic } \\
\text { dermatomal maps }\end{array}$ \\
\hline $\begin{array}{l}\text { Krempen and Smith } \\
(40) \\
\text { Retrospective study } \\
\text { AHRQ score 3/5 } \\
\text { QUADAS score } \\
\text { 11/14 }\end{array}$ & $\begin{array}{l}22 \text { patients } \\
\text { with sciatica }\end{array}$ & $\begin{array}{l}\text { Mechanical } \\
\text { stimulation and } \\
\text { selective nerve } \\
\text { root injections }\end{array}$ & $\begin{array}{l}\text { Concordant } \\
\text { pain response } \\
\text { to injection and } \\
\text { surgical outcome } \\
\text { in } 16 \text { of } 22 \\
\text { patients }\end{array}$ & $\begin{array}{l}18 \text { patients had a positive } \\
\text { result. In the } 16 \text { patients that } \\
\text { underwent surgery after } \\
\text { positive response to the } \\
\text { injection all improved with } \\
\text { surgery and had corresponding } \\
\text { lesions at the level suggested. } \\
\text { All patients had pain relief to a } \\
\text { varying degree. }\end{array}$ & $\begin{array}{l}\text { SNRB is helpful } \\
\text { diagnostically in surgical } \\
\text { planning. } 100 \% \text { sensitivity. }\end{array}$ \\
\hline $\begin{array}{l}\text { Haueisen et al (42) } \\
\text { Retrospective study } \\
\text { AHRQ score } 3 / 5 \\
\text { QUADAS score } 9 / 14\end{array}$ & $\begin{array}{l}105 \text { patients } \\
\text { with sciatica }\end{array}$ & $\begin{array}{l}\text { SNRB post } \\
\text { laminectomy } \\
\text { with surgical } \\
\text { reexploration }\end{array}$ & $\begin{array}{l}\text { Comparison of } \\
\text { surgical findings } \\
\text { with SNRB versus } \\
\text { myelogram }\end{array}$ & $\begin{array}{l}\text { Patients with positive SNRB } \\
\text { documented positive surgical } \\
\text { pathology }\end{array}$ & $\begin{array}{l}55 \text { pts had a positive result } \\
\text { and underwent surgery; } \\
93 \% \text { sensitivity }\end{array}$ \\
\hline $\begin{array}{l}\text { Herron }(47) \\
\text { Retrospective study } \\
\text { AHRQ score } 3 / 5 \\
\text { QUADAS score } 9 / 14\end{array}$ & $\begin{array}{l}215 \text { patients } \\
\text { with leg pain } \\
\text { (78 underwent } \\
\text { surgery) }\end{array}$ & $\begin{array}{l}\text { SNRB prior to } \\
\text { surgery }\end{array}$ & $\begin{array}{l}\text { Comparison of } \\
\text { surgical findings } \\
\text { and outcomes }\end{array}$ & $\begin{array}{l}78 \text { patients underwent surgery. } \\
38 \text { patients }(53 \%) \text { had a good } \\
\text { surgical result. } 16 \text { patients } \\
(23 \%) \text { had a fair result. } 17 \\
\text { patients }(24 \%) \text { had a poor result }\end{array}$ & $\begin{array}{l}\text { SNRB helpful diagnostically } \\
\text { in patients without prior } \\
\text { surgery. } 76 \% \text { sensitivity }\end{array}$ \\
\hline $\begin{array}{l}\text { Dooley et al ( } 43) \\
\text { Retrospective case } \\
\text { series } \\
\text { AHRQ score } 4 / 5 \\
\text { QUADAS score } 10 / 14\end{array}$ & $\begin{array}{l}62 \text { patients } \\
\text { with radicular } \\
\text { symptoms }\end{array}$ & $\begin{array}{l}\text { Mechanical } \\
\text { stimulation with } \\
\text { needle and SNRB } \\
\text { compared with } \\
\text { surgery }\end{array}$ & $\begin{array}{l}\text { Comparison of } \\
\text { surgical outcome } \\
\text { with SNRB } \\
\text { response }\end{array}$ & $\begin{array}{l}44 \text { patients had a positive } \\
\text { result. Surgery confirmed local } \\
\text { pathology in all cases. }\end{array}$ & $\begin{array}{l}\text { SNRB helpful diagnostically } \\
\text { when mechanical } \\
\text { stimulation and SNRB are } \\
\text { concordant. }\end{array}$ \\
\hline $\begin{array}{l}\text { Tajima et al }(41) \\
\text { Prospective case } \\
\text { series } \\
\text { AHRQ score } 3 / 5 \\
\text { QUADAS score } 9 / 14\end{array}$ & 106 patients & \begin{tabular}{|l|} 
Mechanical \\
stimulation with \\
needle and SNRB \\
compared \\
in surgical \\
exploration
\end{tabular} & $\begin{array}{l}\text { Comparison of } \\
\text { SNRB response } \\
\text { to imaging and } \\
\text { surgical findings }\end{array}$ & $\begin{array}{l}\text { In patients with positive } \\
\text { SNRB, imaging and surgical } \\
\text { pathology were concordant }\end{array}$ & $\begin{array}{l}\text { SNRB was helpful } \\
\text { diagnostically in patients } \\
\text { when mechanical } \\
\text { stimulation and SNRB were } \\
\text { concordant. Also the site of } \\
\text { entrapment was consistent } \\
\text { with surgical findings. }\end{array}$ \\
\hline $\begin{array}{l}\text { Van Akkerveeken (46) } \\
\text { Prospective case } \\
\text { series } \\
\text { AHRQ scores 3/5 } \\
\text { QUADAS score 7/14 }\end{array}$ & $\begin{array}{l}46 \text { ( } 37 \text { patients } \\
\text { with disc } \\
\text { protrusions } \\
\text { and } 9 \text { with } \\
\text { metastases) }\end{array}$ & $\begin{array}{l}\text { Mechanical } \\
\text { stimulation } \\
\text { followed by SNRB } \\
\text { with Marcaine }\end{array}$ & $\begin{array}{l}\text { Comparison of } \\
\text { SNRB response } \\
\text { to imaging } \\
\text { and surgical } \\
\text { pathology }\end{array}$ & $\begin{array}{l}\text { Sensitivity } 100 \% \text {. Specificity } \\
90 \% \text {. Positive predictive value } \\
\text { for good surgical result was } \\
\text { excellent at } 70-95 \% \text { depending } \\
\text { on statistics. }\end{array}$ & $\begin{array}{l}\text { SNRB was highly sensitive } \\
\text { and specific with a high } \\
\text { positive predictive value for } \\
\text { surgical outcome. }\end{array}$ \\
\hline $\begin{array}{l}\text { North et al (63) } \\
\text { Randomized single } \\
\text { blind } \\
\text { Prospective study } \\
\text { AHRQ score } 4 / 5 \\
\text { QUADAS score } 7 / 14\end{array}$ & $\begin{array}{l}33 \text { patients } \\
\text { with } \\
\text { radiculopathy }\end{array}$ & $\begin{array}{l}\text { Spinal blocks of } \\
\text { the facets, sciatic } \\
\text { nerve, medial } \\
\text { branch blocks, } \\
\text { and trigger point } \\
\text { blocks }\end{array}$ & $\begin{array}{l}\text { Comparison of } \\
\text { different blocks } \\
\text { to selective nerve } \\
\text { root blocks. }\end{array}$ & $\begin{array}{l}\text { Nerve root blocks had } \\
\text { sensitivities between } 9-42 \% \text {. } \\
\text { Specificity } 24 \% \text {. Sciatic nerve } \\
\text { block was also effective in } \\
\text { relieving pain known to be } \\
\text { proximal to block. }\end{array}$ & $\begin{array}{l}\text { SNRB false positive results } \\
\text { are common and specificity } \\
\text { was low. }\end{array}$ \\
\hline
\end{tabular}


Table 5 Continued. Characteristics of articles included in systematic review of selective nerve root blocks.

\begin{tabular}{|c|c|c|c|c|c|}
\hline $\begin{array}{l}\text { Study/ } \\
\text { Methods }\end{array}$ & Participants & Interventions & Outcomes & Results & Outcomes/Conclusion \\
\hline $\begin{array}{l}\text { Stanley et al (66) } \\
\text { Prospective } \\
\text { consecutive series } \\
\text { AHRQ score } 4 / 5 \\
\text { QUADAS score } \\
12 / 14\end{array}$ & $\begin{array}{l}50 \text { patients } \\
\text { with leg pain }\end{array}$ & $\begin{array}{l}\text { Selective nerve } \\
\text { root blocks and } \\
\text { radiculography } \\
\text { with surgery }\end{array}$ & $\begin{array}{l}\text { Comparison } \\
\text { of SNRB and } \\
\text { radiculography to } \\
\text { surgical findings } \\
\text { and outcomes }\end{array}$ & $\begin{array}{l}\text { Radiculography was not helpful } \\
\text { in indentifying the site of } \\
\text { entrapment. SNRB were helpful } \\
\text { in selecting patients with single } \\
\text { level for surgery. } 20 \text { patients } \\
\text { had a positive result. } 19 \text { patients } \\
\text { underwent surgery. Surgery } \\
\text { confirmed pathology in } 18 \\
(95 \%) \text {. }\end{array}$ & $\begin{array}{l}\text { SNRB may be helpful } \\
\text { in selecting patients for } \\
\text { surgery with single level } \\
\text { entrapment. }\end{array}$ \\
\hline $\begin{array}{l}\text { Shutz et al (39) } \\
\text { Retrospective } \\
\text { AHRQ score } 2 / 5 \\
\text { QUADAS score } 9 / 14\end{array}$ & $\begin{array}{l}23 \text { patients } \\
\text { with sciatica }\end{array}$ & $\begin{array}{l}\text { Selective nerve } \\
\text { root blocks and } \\
\text { surgery }\end{array}$ & $\begin{array}{l}\text { Comparison of } \\
\text { SNRB to surgical } \\
\text { findings and } \\
\text { outcomes }\end{array}$ & $\begin{array}{l}15 \text { patients had positive test } \\
\text { results and underwent surgery. } \\
\text { Surgical findings agreed in } 13 \\
(87 \%) .18 \% \text { of the tests failed } \\
\text { because of failure to stimulate } \\
\text { the desired root. }\end{array}$ & $\begin{array}{l}\text { SNRB may be helpful in } \\
\text { selection of level of surgery. }\end{array}$ \\
\hline $\begin{array}{l}\text { Faraj and } \\
\text { Mulholland (34) } \\
\text { Prospective case } \\
\text { series } \\
\text { AHRQ score } 3 / 5 \\
\text { QUADAS score } \\
12 / 14\end{array}$ & $\begin{array}{l}96 \text { patients } \\
\text { with leg pain }\end{array}$ & $\begin{array}{l}\text { Nerve root } \\
\text { block with and } \\
\text { without a nerve } \\
\text { stimulator, } \\
\text { epidurogram } \\
\text { obtained }\end{array}$ & $\begin{array}{l}\text { Comparison of } \\
\text { response rate of } \\
\text { SNRB with and } \\
\text { without use of a } \\
\text { neurostimulator. }\end{array}$ & $\begin{array}{l}\text { Response rate } 89 \% \text {. Lateral } \\
\text { canal stenosis and battered } \\
\text { root syndrome response better } \\
\text { than for post discectomy or } \\
\text { disc prolapse pain. Response } \\
\text { rate to pain was } 96 \% \text { when } \\
\text { NRI was guided by a } \\
\text { neurostimulator and } 79 \% \text { when } \\
\text { no neurostimulator was used. }\end{array}$ & $\begin{array}{l}\text { Neurostimulation may help } \\
\text { in more precise diagnosis of } \\
\text { nerve root pathology. }\end{array}$ \\
\hline $\begin{array}{l}\text { Anderberg et al (67) } \\
\text { Prospective case } \\
\text { series } \\
\text { AHRQ score } 3 / 5 \\
\text { QUADAS score } \\
12 / 14\end{array}$ & $\begin{array}{l}9 \text { patients } \\
\text { with cervical } \\
\text { radiculopathy }\end{array}$ & $\begin{array}{l}\text { Cervical SNRB } \\
\text { with three } \\
\text { different volumes } \\
(0.6,1.1 \text {, and } 1.7 \\
\mathrm{mL})\end{array}$ & $\begin{array}{l}\text { Comparison } \\
\text { between different } \\
\text { volumes in } \\
\text { producing a } \\
\text { selective diagnostic } \\
\text { nerve root block } \\
\text { utilizing CT } \\
\text { reconstruction } \\
\text { after the block } \\
\end{array}$ & $\begin{array}{l}\text { Possible effect on other nerve } \\
\text { roots than the intended ones } \\
\text { when a larger volume was used } \\
\text { for the root blocks. The spread } \\
\text { related the injected volume as } \\
\text { well as to the local anatomy } \\
\text { (size of foraminal area). }\end{array}$ & $\begin{array}{l}\text { Only } 0.6 \mathrm{~mL} \text { injections } \\
\text { could be accepted for } \\
\text { being selective enough for } \\
\text { diagnostic injections. }\end{array}$ \\
\hline $\begin{array}{l}\text { Wolff et al (35) } \\
\text { Prospective, } \\
\text { randomized, double } \\
\text { blind, crossover } \\
\text { fashion } \\
\text { AHRQ score } 4 / 5 \\
\text { QUADAS score } \\
12 / 14\end{array}$ & $\begin{array}{l}10 \text { patients } \\
\text { with } \\
\text { radiculopathy }\end{array}$ & $\begin{array}{l}\text { Lumbar SNRB } \\
\text { at L4 with } \\
\text { ropivacaine } \\
0.25 \% \text { or } \\
\text { lidocaine } 1 \%\end{array}$ & $\begin{array}{l}\text { Comparison } \\
\text { of SNRB } \\
\text { with baseline } \\
\text { measurements in } \\
\text { pts with chronic } \\
\text { low back pain } \\
\text { radiating to leg } \\
\text { with maximum } \\
\text { pain in one } \\
\text { dermatome }\end{array}$ & $\begin{array}{l}\text { Asymptomatic hypoesthesia } \\
\text { variable in extent and non } \\
\text { dermatomal in } 7 / 10 \text { pts. SNRB } \\
\text { produced no consistent change } \\
\text { in extent and distribution of } \\
\text { hypoesthetic area. }\end{array}$ & $\begin{array}{l}\text { Pre-block assessment of } \\
\text { sensory function is essential } \\
\text { to assess net effects of } \\
\text { SNRB. }\end{array}$ \\
\hline $\begin{array}{l}\text { Wolff et al (36) } \\
\text { Prospective, } \\
\text { observational study } \\
\text { AHRQ score } 3 / 5 \\
\text { QUADAS score } \\
11 / 14\end{array}$ & $\begin{array}{l}71 \text { patients for } \\
\text { L4, L5, and S1 } \\
\text { SNRB }\end{array}$ & $\begin{array}{l}\text { Under } \\
\text { fluoroscopy and } \\
\text { electrostimulation, } \\
0.5 \mathrm{~mL} \text { of } \\
\text { lidocaine and } \\
\text { iohexol injected }\end{array}$ & $\begin{array}{l}\text { Evaluation of } \\
\text { epidural spread } \\
\text { and spread to } \\
\text { adjacent nerve } \\
\text { roots }\end{array}$ & $\begin{array}{l}\text { Epidural spread in } 47 \% \text { of L4 } \\
\text { and } 28 \% \text { of L } 5 \text { blocks. Spread } \\
\text { into adjacent nerve roots in } \\
5 \% .\end{array}$ & $\begin{array}{l}\text { Risk of epidural and/or } \\
\text { adjacent nerve root spread } \\
\text { present even with small } \\
\text { injection volume of } 0.5 \mathrm{~mL} \text {. } \\
\text { The risk is greatest with } \\
\text { medial needle position } \\
\text { in the intervertebral } \\
\text { foramen. Suggest using } \\
\text { electrostimulation along } \\
\text { with fluoroscopy to achieve } \\
\text { optimal SNRB. }\end{array}$ \\
\hline
\end{tabular}

SNRB= selective nerve root block. 
greater with medial needle position in the intervertebral foramen.

Dooley et al (43) performed a retrospective study on mechanical nerve stimulation followed by selective nerve root blocks, followed by surgical treatment. A single root involvement was confirmed in $85 \%$ of patients with concordant pain with mechanical nerve stimulation with needle placement and relief of pain with anesthetic along the nerve root. The evaluation was also helpful in separating patients without spinal problems and those with multiple levels of involvement.

Faraj and Mulholland (34) evaluated the use of a nerve stimulator as they felt that nerve root infiltration (NRI) using local anesthetics and steroids is unpredictable, partly because the exact nerve root giving rise to pain may not be truly infiltrated. The nerve stimulator is advocated to identify the nerve root of concern prior to infiltration.

Anderberg et al in a recent article in 2006 (67) looked at distribution patterns of transforaminal injection in the cervical spine evaluated by multislice computed tomography. In 3 groups of patients, three different volumes $(0.6,1.1$, and $1.7 \mathrm{~mL})$ were injected with a transforaminal technique in the cervical spine. In all the injections, a small amount of contrast media was added. They found that only $0.6 \mathrm{~mL}$ injections could be accepted for being selective enough for diagnostic investigations.

Multiple authors (14,21,23,37-50,69-72) reported the value of selective nerve root blocks in the determination of the symptomatic levels in confounding situations.

\section{Principles}

Selective nerve root blocks can be performed in order to test the hypothesis that a target nerve root is the source of a patient's pain. Selective nerve root block must be performed under fluoroscopic visualization utilizing a low volume local anesthetic of 0.5-1.0 $\mathrm{mL}$. If the pain is not relieved, the nerve root cannot be considered as transmitting the pain. However, if the pain is completely relieved with a properly performed block without leakage into surrounding structures, the nerve root is considered as the source of the pain. As for facet joint block or sacroiliac joint blocks, and provocative discography, no standards have been established to eliminate false-positive responses with transforaminal epidural injections (1-3,31). However, true-positive responses may be secured by performing controlled blocks with placebo injections of nor- mal saline. Comparative local anesthetic blocks which have been shown to be valid in the diagnosis of facet joint pain have not been studied for transforaminal usage. The only study (35) that compared a short acting local anesthetic (lidocaine) with a long acting local anesthetic (ropivacaine) in selective nerve root block used 2 test blocks in a random order as each other's control to raise the validity of the block response. No differences in effect were found between lidocaine and ropivacaine (35). A major criticism of this particular study was that it does not address the issue of anesthetic resistance or of the fallacy of a test utilizing "differential local anesthetics."

\section{Validity}

Selective nerve root blocks have been shown to have face validity. Local anesthetic injected accurately onto the correct target point of the nerve root selectively infiltrates the target nerve, and may provide the validity. Thus, performing the procedure with low volume local anesthetic under fluoroscopic visualization and limiting the injection onto the target nerve will preserve the face validity. However, the construct validity of selective nerve root blocks has not been established. Thus, it is not known in every individual case, whether the response is a true positive or not. Significant false-positive rates have been described with multiple other diagnostic interventional techniques (1-5,26,31,73-76).

In addition to the false-positive result, confounding factors such as psychological issues and sedation have not been studied for selective nerve root blocks.

\section{Standard}

Even though results of biopsy or autopsy are not available to confirm specificity and sensitivity of selective nerve root blocks, surgical confirmation and clinical results provide a reliable gold standard $(6,42,47,66,72-76)$.

Haueisen et al (42) in an early study on patients with post-laminectomy radicular symptoms compared the diagnostic accuracy of spinal nerve root injections with idocaine to myelogram for surgical pathology and outcome. Of the 105 patients studied with selective nerve root injections, 55 underwent surgical reexploration. Selective nerve root injections were accurate in making a diagnosis consistent with surgical pathology in 43 out of the 55 patients, or 93\%; myelogram was accurate in $24 \%$. The surgical outcome at an average of 20 months was improvement in $73 \%$ 
of the patients. They concluded that, in patients with surgically altered anatomy selective nerve root blocks are helpful in making an accurate diagnosis.

Herron (47) examined the response to selective nerve root blocks as a means to assure spinal origin for the pain complaint. The surgical outcomes were as expected with patients having the best outcome for lumbar disc herniation and spinal stenosis and doing poorly with a history of prior surgery. The response to injection was helpful in narrowing potential surgical patients from 215 to 71 patients who subsequently underwent surgical repair.

Tajima (41), in an early study of this technique, compared the response for 106 patients to mechanical stimulation and anesthetic response to myelogram and surgical outcome. Comparison to the normal dye patterns in reference patients and cadaveric dye patterns was also attempted to clarify the role of radiculograms as a diagnostic imaging tool. The disorders studied were diverse but selective nerve root block was helpful in determining the pain level in the majority of patients with corresponding abnormalities found on surgical repair. Additionally it was helpful in limiting the surgical decompression to the area of primary pain generation.

Anderberg et al (67) performed a prospective study on 20 patients with cervical selective nerve root blocks and a comparison of post surgical response. Of the 20 patients studied, 18 had a positive cervical selective nerve root block that corresponded to MRI findings and complete post surgical pain relief.

Schutz et al (39) retrospectively reported on selective nerve root blocks performed on 23 patients. In $15 / 23$ patients an operation was performed at the level indicated by the selective nerve root block. $13 / 15$ (87\%) had positive findings that correlated with the results of the diagnostic block. $18 \%$ of the tests failed because of intolerable pain during the procedure or failure to stimulate the desired root, most often at S1.

\section{Accuracy}

Accuracy of any test is measured by sensitivity and specificity. Specificity is a relative measure of the prevalence of false-positives, whereas sensitivity is the relative prevalence of false-negative results. There are several confounding factors with selective nerve root blocks that may lead to a false-positive result in spite of precautions. There are numerous structures in close proximity that could also affect a false-positive block. Consequently, selective nerve root blocks are considered to have an excessively high level of sensitivity with a moderate or low level of specificity. As compared with sciatic nerve, posterior ramus block, or subcutaneous injection, a selective nerve root block in patients with sciatica has been shown to have high sensitivity $(53,63)$, however, the specificity was judged to be only moderate. In fact the specificity of sciatic nerve block was as good as or equal to a selective nerve root block (66).

The sensitivity and specificity of diagnostic selective nerve root blocks range from 45 to $100 \%$ $(39,40,42,43,46,66-68)$. Schutz et al (39) reported finding a corroborative lesion at the time of surgery in $87 \%$ of patients with a positive diagnostic block. Krempen and Smith (40) reported $100 \%$ surgical confirmation following a positive block. Dooley et al (43) reported 3 out of 51 blocks to be false-positive, providing a specificity of $94 \%$. Stanley et al (66) reported a $95 \%$ specificity. Van Akkerveeken (46) attempted to establish the diagnostic value of selective nerve root injections. In 37 patients with confirmed lumbar radiculopathy, compared to 9 patients with pain due to metastases, it was found that the sensitivity for determining pain of spinal neural origin was $100 \%$. The specificity was studied by comparison to a normal level on imaging and exam with a selective nerve root block, and was $90 \%$. Of the 37 patients with lumbar radiculopathy, some declined surgery. The predictive value for a good outcome was determined with, and without, patients who did not want surgery. If all patients who declined surgery were included in the analysis as surgical failures, the positive predictive value of a good surgical outcome with a positive selective nerve root block was $70 \%$. The positive predictive value was $95 \%$ when patients who had surgery were the only ones included in the analysis. Within this study, selective nerve root injections were a highly sensitive, specific test with high predictive value for surgical outcome.

Anderberg et al (67) reported $96 \%$ specificity. Haueisen et al (42) reported $93 \%$ specificity. Dooley et al (43) reported $85 \%$ specificity.

Anderberg et al (68), in a study in 2006, concluded that for a block to be truly selective enough for diagnostic investigations, only $0.6 \mathrm{~mL}$ of total injectate is acceptable.

However, these high levels of specificity and sensitivity have not been proven in controlled trials. It is imperative to compare these results in light of the evidence shown by North et al (63). 


\section{Diagnostic Validity}

Diagnostic selective nerve root injection is typically performed on a patient with persistent pain when the history, examination, imaging, and electrophysiology testing do not clarify the pain generator. Kikuchi et al (45) estimated that $20 \%$ of patients presenting with radicular pain required diagnostic nerve root blocks. Derby et al (72) reported that patients who failed to obtain sustained relief of radicular pain following the transforaminal blocks were less likely to benefit from subsequent surgical intervention. Manchikanti et al (13), in exploring the role of transforaminal epidural injections in the diagnosis of low back pain of undetermined origin, performed transforaminal epidural injections in 35 patients from a cohort of 120 patients. Of the 35 patients undergoing transforaminal epidural injections, 16 responded with pain relief. Herron (47) found the procedure useful in identifying previously undocumented disc herniations, the symptomatic level in multi-disc herniation, the primary pain generator in the spine-hip syndrome, previously undocumented root irritation and spondylolisthesis, the symptomatic level in multi-level stenosis, and the symptomatic root in patients with documented post operative fibrosis. White (77) supported the use of diagnostic selective nerve root blocks as a pre-surgical test in patients with equivocal anatomic finds. Pang et al (78) utilizing application of spinal pain mapping in the diagnosis of low back pain in 104 cases, reported that lumbar nerve root involvement was present in $44 \%$ of the patients.

\section{Use of Imaging to Increase Sensitivity and Specificity}

Strobel et al (61) examined whether MRI findings of the cervical spine can predict pain relief after selective CT- guided nerve root block and thus assist in appropriate selection of patients who are suitable for the procedure. There was a significant relationship between pain relief level and both location of disk herniation (mean pain reductions of $41 \%$ at median or mediolateral locations and $64 \%$ at foraminal locations) and location of nerve root compromise (mean pain reductions of $19 \%$ at intraspinal, $45 \%$ at foraminal entrance and $58 \%$ at foraminal locations). There was an inverse relationship between pain relief level and presence of spinal canal stenosis (mean pain reductions of $29 \%$ when stenosis is present and $53 \%$ when stenosis is absent). This study highlights the complex nature of the diagnostic test itself and why results are so disparate.

\section{Confounding Variables}

Injection of local anesthetics may spread beyond the target nerve root to surrounding structures, include adjacent dorsal rami, spinal nerves or sinuvertebral nerves, causing a false-positive result. For CTguided lumbar selective nerve root block, Castro et al (79) showed epidural spread in $48 \%$ and spread to an adjacent nerve root in $27 \%$ of cases with their lowest injected volume (i.e., $0.5 \mathrm{~mL}$ ). Wolff et al (65) utilized a combination of fluoroscopy and electrostimulation to perform the selective nerve root block, but still found epidural spread in $47 \%$ of $L 4$ and $28 \%$ of L5 blocks and spread to adjacent nerve roots in $5 \%$. Anatomical variations, such as nerve root abnormalities were found in $14 \%$ of individuals (80). The furcal nerve usually arises from the $L 4$ root level and contributes to both the lumbar and sacral plexuses. Neurologic symptoms, suggestive of 2 root involvement, frequently results from furcal nerve compression (81). Pain relief resulting from blockade of a spinal nerve cannot distinguish between pathology of the proximal nerve or pain transmitted from distal sites by that nerve. Ongoing sciatic pain can be relieved by sciatic nerve block, distal or collateral to any pathology $(82,83)$. Distal referred pain in response to paraspinal noxious stimuli (hypertonic saline) can be prevented by peripheral somatic blockade in the area of referral (84). Finally, pain is purely subjective, often with uncertain pathophysiology. It may be influenced by psychological, social, financial and legal factors, as well as by the efficacy of concurrent therapies such as medications and physical therapy. A significant placebo effect that is directly proportional to the invasiveness of the procedure has been reported $(85,86)$. Thus, performing injections on two or more occasions may minimize the placebo effect.

\section{Methodological Quality}

Methodological Quality of these articles was judged by the criteria described by AHRQ (50) and QUADAS (51) as shown in Tables 2 and 3. The criteria and description of studies are shown in Table 1.

\section{Strength of Evidence}

Based on review of included studies, there is strong evidence that nerve root pain may be relieved with a selective nerve root block. However, the current analysis provides limited evidence for selective nerve root block as a diagnostic tool for spinal pain. The current analysis provides moderate evidence for selective nerve root blocks in the preoperative evaluation of patients 
with negative or inconclusive imaging studies, but with clinical findings of nerve root irritation.

\section{Discussion}

This systematic review of the literature pertaining to selective nerve root block shows that the sensitivity and specificity of selective nerve root block ranges from 45 to $100 \%$. Consequently, diagnostic selective nerve root block may be considered as an effective technique in evaluating patients with multilevel pathology to ascertain which level is the pain generator. Similarly, it may be useful when the location of symptoms seems to conflict with abnormalities identified by imaging studies.

Selective nerve root block has been supported as a presurgical test in patients with equivocal anatomic findings. Further, it was found useful in identifying previous undocumented disc herniation, may be helpful in determining the symptomatic level in multilevel disc herniation, the primary pain generator in the spine-hip syndrome, root irritation with spondylolisthesis, the symptomatic level in multilevel stenosis, and the symptomatic root in patients with postoperative fibrosis. Prevalence of nerve root pain has been reported to be $44 \%$ in one study (78) in patients with low back pain of undetermined etiology after medical history taking, physical examination, radiographic examination, and electrophysiologic examination.

The limitations of our review include the methodological quality of the studies available. The evaluation shows conflicting results. Proponents show good sensitivity and specificity. While others (63) indicate caution and note that the sensitivity of root block is very high whereas its specificity is only moderate. In fact, the specificity of sciatic nerve block was as good as a selective nerve root block. However, the sensitivity of selective nerve root block was high when compared to sciatic nerve block, posterior ramus block, and subcutaneous injection in a cohort of patients with sciatica (63).

In contrast to facet joint blocks, diagnostic selective nerve root block has been confirmed with surgical examination apart from clinical results. However, the specific limitations for interventional techniques also extend to transforaminal epidural injections. Further, selective nerve root blocks lack a proven methodology to avoid false-positives. Utilizing the pain relief in a given patient as a standard can be neither confirmed nor denied. As a result, in terms of specificity and sensitivity, the true accuracy of selec- tive nerve root blocks based on pain relieving phenomenon is uncertain. Further, selective nerve root blocks are more similar to physical examination than most laboratory tests used in clinical medicine, which have an absolute gold standard for comparison to determine their true accuracy. Saal (6) described the general principles of diagnostic testing and appraised current diagnostic techniques as they relate to painful lumbar spine disorders. Rather than concluding that current diagnostic tests are invalid or should be used less, Saal (6) suggested their results should be considered in the light of inaccuracies present in all diagnostic tests in medicine. Clinicians can use this perspective to prioritize the data from these tests along with earlier clinical data gathered from the history, physical examination, and noninterventional imaging studies. With this information in hand, the clinician and patient can choose appropriate therapies for the given painful spinal disorder (6,87-90).

There have been no systematic reviews to compare our results with prior reviews. However, Boswell et al (2) in preparation of guidelines for interventional techniques summarized the evidence for selective nerve root blocks as moderate in the preoperative evaluation of patients with negative or inconclusive imaging studies, but with clinical findings of nerve root irritation.

The inability of the physician to provide appropriate and accurate diagnosis for a patient with chronic spinal pain is frustrating not only for the patient but for the physician. Without clearcut findings from physical examination, history, radiologic evaluation, electrophysiologic examination, and psychological evaluation, and once facet joint pain and discogenic pain are ruled out, the diagnostic selective nerve root block may be the only alternative. Use of neurostimulation and appropriate imaging studies may help improve results and outcomes of diagnostic nerve root blocks. A comprehensive evaluation including imaging studies before performing a diagnostic block may help predict response to a diagnostic nerve root block.

\section{Conclusion}

There is moderate evidence for the effectiveness of selective nerve root block as a diagnostic tool in spinal disorders with radicular features. Although limited, available literature is supportive of selective nerve root blocks as a diagnostic test for equivocal radicular pain. Further research is necessary to determine the 
accuracy of selective nerve root blocks in predicting surgical and non-surgical treatment outcomes compared to other established diagnostic imaging and electrodiagnostic tests.

\section{Acknowledgments}

The authors wish to thank the professional librarian at Vanderbilt University Medical Center and its Evidence Based Wing, Ms Shannon Potter, for conducting the search.

\section{References}

1. Everett CR, Shah RV, Sehgal N, McKenzie-Brown, AN. A systematic review of diagnostic utility of selective nerve root blocks. Pain Physician 2005; 8:225233.

2. Boswell MV, Shah RV, Everett CR, Sehgal N, McKenzie Brown AN, Abdi S, Bowman RC, Deer TR, Datta S, Colson JD, Spillane WF, Smith HS, Levin LF, Burton AW, Chopra P, Staats PS, Wasserman RA, Manchikanti L. Interventional techniques in the management of chronic spinal pain: Evidence-based practice guidelines. Pain Physician 2005; 8:1-47.

3. Abdi S, Datta S, Lucas LF. Role of epidural steroids in management of chronic spinal pain: A systematic review of effectiveness and complications. Pain Physician 2005; 8: 127-143.

4. Boswell MV, Hansen HC, Trescot AM, Hirsch JA. Epidural steroids in the management of chronic spinal pain and radiculopathy. Pain Physician 2003; 6:319-334.

5. Manchikanti L, Staats P, Singh V, Schultz D, Vilims B, Jasper J, Kloth D, Trescot A, Hansen H, Falasca T, Racz G, Deer T, Burton A, Helm S, Lou L, Bakhit C, Dunbar E, Atluri S, Calodney A, Hassenbusch S, Feler C. Evidence-based practice guidelines for interventional techniques in the management of chronic spinal pain. Pain Physician 2003; 6:380.

6. Saal JS. General principles of diagnostic testing as related to painful lumbar spine disorders: a critical appraisal of current diagnostic techniques. Spine 2002; 27:2538-2545.

7. Manchikanti L, Singh V, Kloth DS, Slipman CW, Jasper JF, Trescot AM, Varley KG, Atluri SL, Giron C, Curran MJ, Rivera JJ, Baha A, Bakhit CE, Reuter M. Interventional techniques in the management of chronic pain: Part 2.o. Pain Physician 2001; 4:24-96.

8. Manchikanti L, Singh V, Bakhit CE, Fellows B. Interventional techniques in the management of chronic pain. Part 1.0. Pain Physician 2000; 3:7-42.

9. O'Neill C, Derby R, Kenderes L. Precision injection techniques for diagnosis and treatment of lumbar disc disease. Semin Spine Surg 1999; 11:104-118.

10. Bogduk N. Low back pain. In Clinical Anatomy of Lumbar Spine and Sacrum. Fourth ed. Churchill Livingstone, New York, 2005; pp 183-216.

11. Wheeler AH, Murrey DB. Chronic lumbar spine and radicular pain: Pathophysiology and treatment. Curr Pain Headache Rep 2002; 6:97-105.

12. Bogduk N, McGuirk B. Causes and sources of chronic low back pain. In Bogduk N, McGuirk B, eds. Medical Management of Acute and Chronic Low Back Pain, An Evidence-Based Approach. Pain Research and Clinical Management, Vol 13, Amsterdam, Elsevier Science BV, 2002, 115-126.

13. Manchikanti L, Singh V, Pampati VS, Damron KS, Barnhill RC, Beyer C, Cash KA. Evaluation of the relative contributions of various structures in chronic low back pain. Pain Physician 2001; 4:308-316.

14. Riew $K D$, Yin $Y$, Gilula L, Bridwell $K H$, Lenke LG, Lauryssen C, Goette K. The effect of nerve root injections on the need for operative treatment of lumbar radicular pain. J Bone Joint Surg Am 2000; 82A:1589-1593.

15. Kraemer J, Ludwig J, Bickert U, Owczarek V, Traupe M. Lumbar perineural epidural injection: a new technique. Eur Spine J 1997; 6:357-361.

16. Thomas E, Cyteval C, Abiad L, Picot MC, Taourel P, Blotman F. Efficacy of transforaminal versus interspinous corticosteroid injection distal radiculalgia - a prospective, randomized, double-blind study. Clin Rheum 2003; 22:299-304.

17. Karppinen J, Malmivaara A, Kurunlahti M, Kyllonen E, Pienimaki T, Nieminen $P$, Ohinmaa A, Tervonen O, Vanharanta $\mathrm{H}$. Periradicular infiltration for sciatica: A randomized controlled trial. Spine 2001; 26:1059-1067.
18. Vad VB, Bhat AL, Lutz GE, Cammisa F. Transforaminal epidural steroid injections in lumbosacral radiculopathy: A prospective randomized study. Spine 2002; 27:11-15.

19. Lutz GE, Vad VB, Wisneski RJ. Fluoroscopic transforaminal epidural steroid injections: An outcome study. Arch Phys Med Rehabil 1998; 79:1362-1366.

20. Bush K, Hillier S. Outcome of cervical radiculopathy treated with periradicular epidural corticosteroid injections: A prospective study with independent clinical review. Eur Spine J 1996; 5:319325.

21. Weiner BK, Fraser RD. Foraminal injection for lateral lumbar disc herniation. J Bone Joint Surg Br 1997; 79B:804-807.

22. Manchikanti L, Pampati VS, Rivera JJ, Beyer C, Damron K, Barnhill R. Caudal epidural injections with Sarapin steroids in chronic low back pain. Pain Physician 2001; 4:322-335.

23. Rosenberg SK, Grabinsky A, Kooser A, Boswell M. Effectiveness of transforaminal epidural steroid injections in low back pain: a one year experience. Pain Physician 2002; 5:266-270.

24. Wang JC, Lin E, Brodke DS, Youssef JA. Epidural injection for the treatment of symptomatic lumbar herniated discs. I Spinal Disord Tech 2002; 15:269-272.

25. Karppinen J. Letter in response to periradicular infiltration for sciatica. Spine 2002; 27:216-217.

26. Manchikanti L. Transforaminal lumbar epidural steroid injections. Pain Physician 2000; 3:374-398.

27. Manchikanti L, Pakanati RR, Pampati V. Comparison of three routes of epidural steroid injections in low back pain. Pain Digest 1999; 9:277-285.

28. Manchikanti L, Cash KA, Pampati V, Damron KS, McManus CD. Evaluation of lumbar transforaminal epidural injections with needle placement and contrast flow patterns: A prospective, descriptive report. Pain Physician 2004; 7:217-223. 
29. Karppinen J, Ohinmaa A, Malmivaara A, Kurunlahti M, Kyllonen E, Pienimaki T, Nieminen P, Tervonen O, Vanharanta $\mathrm{H}$. Cost effectiveness of periradicular infiltration for sciatica: Subgroup analysis of a randomized controlled trial. Spine 2001; 26:2587-2595.

30. Manchikanti L, Singh V. Periradicular infiltration for sciatica. Spine 2002; 27:215-217.

31. Bogduk N. Lumbar spinal nerve blocks. In Practice Guidelines for Spinal Diagnostic and Treatment Procedures, 1st edition. International Spine Intervention Society, 2004, pp 3-19.

32. Gajraj NM. Selective nerve root blocks for low back pain and radiculopathy. Reg Anesth Pain Med 2004; 29:243256.

33. Datta S, Pai U. Selective nerve root block- is the position of the needle transforaminal or paraforaminal? Call for a need to reevaluate the terminology. Reg Anesth Pain Med 2004; 29:616617.

34. Faraj AA, Mulholland RC. The value of nerve root infiltration for leg pain when used with a nerve stimulator. Eur Spine J 2006; 15:1495-1499.

35. Wolff AP, Groen GJ, Wilder-Smith $\mathrm{OH}$, Richardson J, van Edmond J, Crul BJ. Do diagnostic segmental nerve root blocks in chronic low back pain patients with radiation to the leg lack distinct sensory effects? A preliminary study. $\mathrm{Br} / \mathrm{An}$ aesth 2006; 96:253-258.

36. Wolff AP, Groen GJ, Wilder-Smith OH. Influence of needle position on lumbar segmental nerve root block selectivity. Reg Anesth Pain Med 2006; 31:523530.

37. Steindler A, Luck JV. Differential diagnosis of pain in the low back: Allocation of the source of the pain by the procaine hydrochloride method. JAMA 1938; 110:106-113

38. MacNab I. Negative disc exploration: An analysis of the causes of nerve root involvement in sixty-eight patients. J Bone Joint Surg [AM] 1971; 53A:891-903.

39. Schutz H, Lougheed WM, Wortzman G, Awerbuck BG. Intervertebral nerve-root in the investigation of chronic lumbar disc disease. Can J Surg 1973; 16:217221.

40. Krempen JF, Smith BS. Nerve root injection: A method for evaluating the etiology of sciatica. J Bone Joint Surg [AM] 1974; 56A:1435-1444.

41. Tajima T, Furukawa K, Kuramochi E. Selective lumbosacral radiculography and block. Spine 1980; 1:68-77.
42. Haueisen DC, Smith BS, Myers SR, Pryce ML. The diagnostic accuracy of spinal nerve injection studies. Clin Orthop Rel Res 1985; 198:179-183.

43. Dooley JF, McBroom RJ, Taguchi T, MacNab I. Nerve root infiltration in the diagnosis of radicular pain. Spine 1988 ; 13:79-83.

44. Castro WH, van Akkerveeken PF. Der diagn ostische Wert der selektiven lumbalen Nervenwurzelblockde. Z Orthop Ihre Grenzgeb 1991; 129:374-379.

45. Kikuchi S, Hasue M, Nishiyama K. Anatomic and clinical studies of radicular symptoms. Spine 1984; 9:23-30.

46. Van Akkerveeken PF. The diagnostic value of nerve root sheath infiltration. Acta Orthop Scand Suppl 1993; 251:6163.

47. Herron LD. Selective nerve root block in patient selection for lumbar surgery: Surgical results. I Spinal Disord 1989; 2:75-79.

48. Hoppenstein R. A new approach to the failed back syndrome. Spine 1980; 5:371-379.

49. Nachemson A. Newest knowledge of low back pain: A critical look. Clin Orthop Rel Res 1992; 279:8-20.

50. West S, King V, Carey T, Lohr K, McKoy N, Sutton S, Lux L. Systems to rate the strength of scientific evidence. Evidence Report/Technology Assessment No. 47 University of North Carolina: Agency for Healthcare Research and Quality. AHRQ Publication No. 02-E016; April 2002.

51. Whiting P, Rutjes A, Reitsma J, Bossuyt P, Kleijnen J. The Development of QUADAS: A tools for the quality assessment of studies of diagnostic accuracy included in systematic reviews. $B M C$ Med Res Methodol 2003; 3:25.

52. Narozny M, Zanetti M, Boos N. Therapeutic efficacy of selective nerve root blocks in the treatment of lumbar radicular leg pain. Swiss Med Wkly 2001; 131:75-80.

53. Lee JW, Kim SH, LeeIS, Choi J-Y, Hong SH, Kang HS. Therapeutic effect and outcome predictors of sciatica treated using transforaminal epidural steroid injection. AJR 2006: 187:1427-1431.

54. Cyteval C, Fescquet N, Thomas E, Decoux E, Blotman F, Taourel P. Predictive factors of efficacy of periradicular corticosteroid injections for lumbar radiculopathy. Am J Neuroradiol 2006; 27:978-982.

55. Yang SC, Fu TS, Lai PL, Niu CC, Chen LH, Chen WJ. Transforaminal epidural steroid injection for discectomy candidates: An outcome study with minimum of two years follow up. Chang Gung Med I 2006; 29: 93-99.

56. Ng L, Chaudhary N, Sell P. The efficacy of corticosteroids in periradicular infiltration for chronic radicular pain. Spine 2005; 30:857-862.

57. Lee JW, Kim SH, Choi JY, Yeom JS, Kim KJ, Chung SK, Kim HJ, Kim C, Kwack KS, Kwon JW, Moon SG, Jun WS, Kang HS. Transforaminal epidural steroid injection for lumbosacral radiculopathy: preganglionic versus conventional approach. Korean J Radiol 2006; 7:139144 .

58. Kolstad F, Leivseth G, Nygaard OP. Transforaminal steroid injections in the treatment of cervical radiculopathy. A prospective outcome study. Acta Neurochir (Wien) 2005; 147:1065-1070.

59. Groenemeyer DH, Gevargez A, Schindler O, Schirp S, Braun M. CTguided periradicular injections of corticosteroids in the management of lumbar radiculopathy associated with disk herniation. J Radiol 2002;1-12.

6o. Schmid G, Vetter S, Bottmann D, Strecker EP. CT-guided epidural/perineural injections in painful disorders of the lumbar spine: Short- and extended-term results. Cardiovasc Intervent Radiol 1999; 22:493-498.

61. Strobel K, Pfirrmann CW, Schmid M, Hodler J, Boos N, Zanetti M. Cervical nerve root blocks: indications and role of MR imaging. Radiology 2004; 233:87-92.

62. Koning HM, Koning AJ. Prolonged pain relief following selective nerve root infiltration. Pain Clinic 2003; 15:225233.

63. North RB, Kidd DH, Zahurak M, Piantadosi S. Specificity of diagnostic nerve blocks: A prospective, randomized study of sciatica due to lumbosacral spine disease. Pain 1996; 65:77-85.

64. Slipman CW, Plastaras CT, Palmitier RA, Huston CW, Sterenfeld EB. Symptom provocation of fluoroscopically guided cervical nerve root stimulation: Are dynatomal maps identical to dermatomal maps? Spine 1998; 23:2235-2242.

65. Wolff AP, Groen GJ, Crul BJ. Diagnostic lumbosacral segmental nerve blocks with local anesthetics: a prospective double-blind study on the variability and interpretation of segmental effects. Reg Anesth Pain Med 2001; 26:147-155.

66. Stanley D, McLaren MI, Euinton HA, Getty CJ. A prospective study of nerve 
root infiltration in the diagnosis of sciatica: A comparison with radiculography, computed tomography, and operative findings. Spine 1990; 6:540-543.

67. Anderberg L, Annertz M, Brandt L, Saveland H. Selective diagnostic cervical nerve root block - correlation with clinical symptoms and MRI-pathology. Acta Neurochir 2004; 146:559-565.

68. Anderberg L, Saveland H, Annertz M. Distribution patterns of transforaminal injections in the cervical spine evaluated by multi-slice computed tomography. Eur Spine J 2006; 15:1465-1471.

69. Beattie PF, Meyers SP, Startford P, Millard RW, Hollenberg GM. Associations between patient report of symptoms and anatomic impairment visible on lumbar magnetic resonance imaging. Spine 2000; 23:819-828.

70. Porter D, Valentine A, Bradford R. A retrospective study to assess the results of CT-directed perineural root infiltration in a cohort of 56 patients with low back pain and sciatica. Br J Neurosurg 1999; 13:290-293.

71. Slosar P, White A, Wetzel F. Controversy: The use of selective nerve root blocks: Diagnostic, therapeutic, or placebo? Spine 1998; 23:2253-2256.

72. Derby R, Kine G, Saal JA, Reynolds J, Goldthwaite N, White AH, Hsu K, Zucherman J. Response to steroid and duration of radicular pain as predictors of surgical outcome. Spine 1992; 17 (Suppl):176-183.

73. North RB, Kidd DH, Campbell JN, Long DM. Dorsal root ganglionectomy for failed back surgery syndrome: A 5- year follow-up study. J Neurosurg 1991; 74:236-242.

74. Boswell MV, Singh V, Staats PS, Hirsch JA. Accuracy of precision diagnostic blocks in the diagnosis of chronic spinal pain of facet or zygapophysial joint origin: A systematic review. Pain Physician 2003; 6:449-456.

75. Sehgal N, Shah RV, McKenzie-Brown A, Everett CR. Diagnostic utility of facet (zygapophysial) joint injections in chronic spinal pain: A systematic review of evidence. Pain Physician 2005; 8:211-224.

76. McKenzie-Brown AM, Shah RV, Sehgal $\mathrm{N}$, Everett CR. A systematic review of sacroiliac joint interventions. Pain Physician 2005; 8:115-125.

77. White A. Injection techniques for the diagnosis and treatment of low back pain. Orthop Clin N Am 1983; 14:553567.

78. Pang WW, Mok MS, Lin ML, Chang DP, Hwang $\mathrm{MH}$. Application of spinal pain mapping in the diagnosis of low back pain - analysis of 104 cases. Acta Anaesthesiol Sin 1998; 36:71-74.

79. Castro WMH, Gronemeyer D, Jerosch J, Seibel R, Lorenz G, Beutelstahl D, Ohlbrecht $\mathrm{K}$, Gohlke H. How reliable is lumbar nerve root sheath infiltration. Eur Spine J 1994; 3:255-257.

80. Kadish L, Simmons E. Anomalies of the lumbosacral nerve roots. An anatomical investigation and myelographic study. J Bone Joint Surg Br 1984; 66:411-416.

81. Kikuchi S, Hause M, Nishiyama K, Ito T. Anatomic features of the furcal nerve and its clinical significance. Spine 1986; 11: 1002-1007.

82. Xavier A, Farrell C, McDanal J, Kissin I. Does antidromic activation of nociceptors play a role in sciatic radicular pain? Pain 1990; 40:77-79.

83. Kissin I, Xavier A, McDanal J. Blockade of sciatic nerve branches relieves sciatic radicular pain. Anesth Analg 1989; 69: 262-263.

84. Hockaday J, Whitty C. Patterns of referred pain in the normal subject. Brain 1967; 90: 481-496.

85. Beecher $\mathrm{H}$. The powerful placebo. JAMA 1955; 159: 1602-1606.

86. Turner J, Deyo R, Loeser J, Von Korff M, Fordyce $\mathrm{W}$. The importance of placebo effects in pain treatment and research. JAMA 1994; 271: 1609-1614.

87. Deyo R, Rainville J, Kent D. What can the history and physical examination tell us about low back pain? JAMA 1992; 268:760-765.

88. Griner PF, Mayewski RJ, Mushlin Al, Greenland P. Selection and interpretation of diagnostic tests and procedures: Principles and applications. Ann Intern Med 1981; 94:553-597.

89. Ito $M$, Incorvaia KM, Yu SF, Fredrickson BE, Yuan HA, Rosenbaum AE. Predictive signs of discogenic lumbar pain on magnetic resonance imaging with discography correlation. Spine 1998; 23:1252-1258.

90. Nicoll D, Pignone M. Basic principles of diagnostic test use and interpretation. In Nicoll D et al (eds). Pocket Guide to Diagnostic Tests, 3rd ed. McGraw-Hill, New York 2001, pp 1-21. 